\title{
Study on Counter-Terrorism Strategy based on the Characteristic of the Terrorism Communication
}

\author{
Na Han ${ }^{1, ~ a, ~ H u a n l e ~ L i ~}{ }^{1, b}$, Guang Yang ${ }^{1, c}$ \\ ${ }^{1}$ Criminal Investigation and Counter Terrorism, People's Public Security University of China, \\ Beijing, China. \\ axthanna@126.com, bhuanle0925@126.com, c1103027993@qq.com
}

\begin{abstract}
With the support of technology in the new era, the terrorism activities present many new characteristics. An increasing number of terrorist organizations use new media to promote extreme ideas, release terrorism information, recruit group participants and plot terrorist activities. Besides the hard power, we should also use soft power to disorganize the terrorism's foundation in terms of thoughts and public opinions. Therefore, introducing the communication has great significance to counter-terrorism. We can establish the national counter-terrorism strategic communication mechanism and fuse the work with politics, diploma, national-defense, religion and so on. Therefore, the information resource and other resource can be deeply reorganized and the counter-terrorism efficiency can be enhanced.
\end{abstract}

Keywords: Counter terrorism, Counter terrorism strategy, Terrorism communication, Propaganda.

\section{Introduction}

The Global Terrorism Index 2015 suggested that after 9•11, global terrorist activities nearly increased for 5 times, and the casualty of almost 18,000 died of terrorist attack in 2013, with year-onyear growth of $61 \%$, released by The Economic policy Institute and the Institution for Economics and Peace. [1]Ravaging of terrorism has brought large disasters and pains to all over the world, including China. Compared to "previous" terrorism, the instrumental zed information communication is an important characteristic and core element of "current" terrorism, as a result, there is a closer relationship between terrorist activity and information communication. Especially in the new media era, the communication of terrorist information has performed outstanding media features. In brief, it is of great importance to analyze the effect and features communication in terrorist activity and make corresponding countermeasures to anti-error work. At present, strategic communication theory has been applied into anti-terror campaign by some countries and national organizations and made obvious effect. Chinese related departments should also make innovative anti-terror thinking, besides tough strategies, we can also, adapting to times, actively explore and innovate the anti-terrorist strategic communication mechanism and strategy suited to Chinese national conditions from the perspective of communication.

Currently, terrorists from all over the world construct their own "Terrorism Discourse System" with diversified communication channels. Extremely distorting doctrines, they brainwash participants through low cost, modernized and real-time communication media. Terrorism communication is the process that terrorists achieve their own political purposes through exchanging information. In this process, the media, as a special social tool, working as information distributor, member organizer and funds raiser, launched psychological warfare with the state entities throughout the world. To some extent, it is the use of the media to communicate terrorism that is an important part of the terrorist's to implement terrorist activities and achieve their political purposes.

\section{Relations Between Media and Terrorism}

\subsection{As the Content of the Media: A Platform to Release the Terrorist Information}

Simon Cottles, the Britain scholar, held that in modern society, the press occupies a central position in conflicts communication, and all parties began to manage their public image and information and compete for the access to the media and the right of event interpretation in order to pursue their own 
interests. [2] In recent years, terrorist organization has raised the communication to a strategic level. Apart from using various methods to influence the information communication through traditional media, terrorist organization has also run their own media to communicate their terrorism ideology, propagate their political proposition and recruit potential terrorists to join the "jihad" to reach their political purposes. With the arrival of the new media era, terrorist organization has upgraded their communication to precise communication and tried to handle three relationships through information communication and exchanges: the relationship between members and its potential supporters, the relationship with unbelievers, western countries and the public, and the relationship with the media. Terrorist organization has shaped their own global image and communicated their ideologies through the concept of strategic integration and communication.

With the development of media technology, communication has also been developed from mass to niche and precise. Terrorist organization will also strategically choose the publicity target and actively engage in "agenda setting" in order to attract more potential "mujahedeen" to implement extreme terrorist activities in a wider region. Under the context of radical terrorism, terrorist organizations model "Jihad" as a defensive and offensive act against external disgrace, and summon "Jihad" supporters and activists to participate in the war. After the terrorist incident, terrorist organizations also actively came out to admit and praise them at the religious level thus to encourage more Muslims to join the jihad against the West and pagans.

\subsection{As A Channel of Media: A Platform for Multiple Interactive Participation}

The propaganda models of terrorist activities are different at all stages of history. Communication not only serves as a propaganda means, but also provides a multiple channels for spreading terrorist ideas. Terrorists and potential audiences participate in spreading terrorist information and terrorist activities on a multiple platform. At present, with the continuous changes of media forms, the propaganda of terrorist organizations has made its current pluralistic propaganda from the fact that terrorist attacks were conducted solely by entities to launch mass media. A large number of terrorist organizations shifted from physical attacks to online propaganda. On the Internet, terrorists can share and exchange information, raise funds, train techniques, propaganda ideologies and coordinate attacks through websites, BBS forums, chat rooms and social media. With the generalized use of Twitter, Facebook, and YouTube and other social media apps and decentralization, anonymity, widespread communication and Trans nationality of mobile internet, terrorist organization has gradually taken note of the important value of using the media to spread terror. They have set up accounts in social media, with the help of social networking sites to induce the public, raise large amounts of money relying on the network, and agitate terrorist attacks through online videos and eperiodicals to largely improve their influence. In recent years, cyber terrorist activities have intensified with the trend of turning from network propaganda, training, recruitment and fund raising to cyber-attacks.

\subsection{Media as A Tool: A Platform for Social Mobilization}

In the era of mass media, the tool attribute of media is limited to the propaganda of terrorist ideas and the exchange of organizational personnel within a certain range. However, with the development of the Internet and social media, in particular, the instrumentalities of the media show the characteristics of social mobilization. Terrorist's convergence online by using the Internet and exhibit two kinds of orientation: one is offline violent terrorist activities. At this time, the online media has become a means and a way for terrorists to mobilize terrorist activities. Terrorists communicate ideology, organize mobilization, conduct orders and command operations through the Internet and other new media means in order to tie in with or develop offline terrorist activities; the other is the online collective acts of violence and terrorism, while online media provides terrorists with sites and tools. Terrorists launch anti-social activities such as hacking, cyber-ideological communications, cyber protests and rumors, and raising funds online in cyber-virtual communities.

In propaganda, terrorists will vilify pagans and their countries in order to win the sympathy of Muslim society and their indignation at western countries. 
In this discourse-shaped "asymmetrical war," it is the terrorist organizations that have exploited the dissatisfaction of local Muslims with the so-called unfair treatment to incite them to join the team of the non-patriotic jihadists.

In a self-media environment, it is easier for terrorist groups to freely encourage their followers to participate in the "jihad" and then develop into "lone wolf" terrorists, massacring innocent people with cruelty. On social media. Terrorist organizations have targeted young people who have the tendency to religious extremism as the main motivators. They are consumers as well as communicators. The two-way interaction between them has resulted in more and smaller organizational structures. In modern terrorist activities, terrorists make full use of the features of new media to carry out their activities. [3]

\subsection{As A Median of Organization: Management Platform of Terrorist Network}

Under the influence of internet media and mobile social media, the management network of terrorist organizations has changed from the traditional stratification and virtualization to the flattening and fragmentation. During this process, the initiation and directing of terrorist activities have deviated from the traditional entities' leadership and mass attack, replaced by the network longdistance command and flat management structure. The structural features of the traditional terrorist organizations are mainly manifested as the "pyramid" of the hierarchy [4]: top-level planning, grassroots implementation, and command orders issued at different levels. Planners are at the top of the pyramid and are responsible for the command of terrorist activities, the formulation of terrorist strategies and the organization of ideological structure; and then the managers are responsible for the management of terrorist activities in all branches and the implementation of the plan in headquarter; Thirdly, the active supporters of terrorist activities around the world mainly provide services for terrorist organizations in communicating, hiding, gathering information, logistics and so on. Lastly, they are potential supporters of terrorist organizations who are not directly involved in terrorist activities but mentally sponsor, which is a group of people who are very easy to transform and implement violent terrorist activities.

However, after entering the 21 st century, terrorist organizations emerged in a flattening trend. The attacks as "lone wolf" have been gradually increasing. They have long been eroded by extremist ideologies in the Internet and their organizational planning may only come from a small scale of Moment in We chat. Many potential ultra-extreme participants may, over the long term, be bewitched and instigated by terrorists in social media, and may be able to move from an extreme mind-set to action in a matter of moments and implement "jihad" under the remote leadership.

Prior to the implementation of the terrorist activities, each network communicated with one another and promptly reached concerted action to promote the escalation of acts of terrorism or "lone wolf" suicide attacks to a certain extent. Compared with the traditional large-scale organized terrorist activities, this kind of terrorist activities planned by the online media organizations is more subtle and uncertain, which has made it more difficult for the anti-terrorism departments to make advance predictions and has brought many problems in counter-terrorism work new challenge.

\section{The Implementation of Counter Terrorism Communication Strategy}

We have entered into an era of digital communication, where all information are transferred and communicated with great freedom and to some extent, with less surveillance by some government. The circulation of terrorism information can be defined as the digital communication, that is to say, internet is a type of communication media, as well as a way of attacking. Terrorists always utilize internet to launch terrorist attacks, take actions relating cyber and even directly launch cyber-attacks. Internet has become the main battle field for terrorists to spread terrorist news, recruit members, collect money and launch spy wars. The "Jihad" communication through the internet by terrorists underwent three phases, that is the 1980s- the 1990s when 1.0 official website was prevalent, the 1990s to 2008 when cyber forums and chatting rooms were popular, and the time up to now when social interactional communication through social media. Currently, forms of cyber terrorism mainly 
refer to establishing websites, advocating on some popular social media, e-mail linking, sharing terrorism videos and audios via network disks, or direct attacks by technologies to reach for some purposes concerning "Jihad". Lots of countries are endeavoring to combat cyber terrorism, take shared efforts on international policing, intelligence and technological cooperation to work together to fight against cyber terrorism.

Counter-terrorism work consists of two aspects: Firstly, combat, which means that we must, according to law, take actions to combat terrorists and terrorist activities which were found; secondly prevention, that is to say, in addition to attempt to eliminate the sprout of terrorist activities that were to implement by terrorists in the state, we should also prevent the proliferation of terrorist ideas and the expansion of terrorist organizations. In the long run, preventive work is even more important. Therefore, we should take counter terrorism strategic communication as a key force to prevent the terrorism ideas mobilizing people.

\subsection{Integrate Resources and Establish the National Counter-Terrorism Strategic Communication Organization}

The core of the strategic communication mechanism is the establishment of a unified and authoritative strategic communication organization system. The system can be divided into two levels: a leading agency and a running agency.

Governing Bodies: Under the National Security Council, a leading group for the national counterterrorism strategic communications will be set up, whose members come from the departments of public security, diplomacy, national defense, judiciary, and propaganda, ethnic, religious and financial sector and so on. The main function of this leading group is to carry out the top-level design and resource integration of the national anti-terrorist strategy communication according to the national counter-terrorist goals and needs, including formulating mid-term and long-term plans, identifying recent work priorities, coordinating relevant departmental resources and work, and conducting overall command of major counter-terrorism strategic communications tasks and so on.

Operating Mechanism: In the Ministry of Public Security, a national counter-terrorism strategic communication center may be set up to carry out the specific work of the counter-terrorism strategic communication. The center belongs to the national leading group for the counter-terrorism strategic communications under the National Security Council, which can draw manpower from relevant departments and public opinion departments of counter-terrorism. Its main tasks are as following: Firstly, taking charge of the daily spread of counter-terrorism strategies in line with the long-term national counter-terrorism objectives and aim at creating a favorable public opinion environment for counter-terrorism; and secondly, formulating and implementing a major strategic communications project plan in line with the actual needs of the national counter-terrorism work to achieve better results.

\subsection{Take the Initiative to Respond to The Establishment of Early Warning Mechanism Against the Spread of Information}

Under normal circumstances, mature countries will establish a set of scientific early-warning system for crisis monitoring to monitoring the crisis of the incubation period in a timely manner to minimize the harm. Terrorism activity, though often erupted as a contingency, often carries many precursors and warnings. Therefore, from the perspective of strategic communications, it is particularly important to establish a set of quick mechanisms for early-warning in counter-terrorism work. It can defuse terrorist activities at a very early stage and dramatically reduce the impact and harm of terrorism.

The mechanism for early-warning of fighting against communicating terrorism information target mainly three aspects: Firstly, information monitoring on terrorist activities. It can collect and monitor all kinds of information communicated by terrorists through various means; secondly, information evaluating on terrorist activities. It can evaluate and comprehensively analyze terrorist information and their harmfulness and controllability; thirdly, information processing. According to its harmfulness and controllability, timely warning and recommendations should be sent to the relevant 
departments of counter-terrorism. The establishment of an early-warning mechanism against the spread of counter-terrorism information needs to coordinate the resources of relevant government departments and the media, establish a technologically advanced information platform and a set of scientific and effective information monitoring workflow and an information evaluation system.

\subsection{Bring Their Own Advantages to Full Play to Implement Layered Communication}

In the past, China's reports of terrorism-related incidents showed a very singular situation. All the media speak in the same way, the same style and repeated communication. Such an approach runs counter to the laws governing the propagation of news and information in the new era and does not suit the changes and needs in counter-terrorism work in the new situation, so we should make breakthroughs and changes. According to the reality of the diversified development of the Chinese media, in the spreading of counter-terrorism in the future, communication can be layered depended on different attributes of media:

The first level is the central government media. The central news agency such as Xinhua News Agency, People's Daily and CCTV must take on the responsibility of conveying official voices. They must hold the position of authority and rigidity in the counter-terrorism issues concerning China.

The second level is the market-oriented traditional media. The media other than Party newspapers can basically be called market-oriented media, and they can make social voices on behalf of different social strata. Of course, there must be a theme, but with many levels and more than one discourse around, which makes it more flexible and diversified. It can issue diversified voices concerning the counter-terrorism issue involving China in a timely and multi-angle manner.

The third level is all kinds of new media. Internet media, especially current extremely popular social media, is a free speech market for grassroots people. Such media should make private voices, should be diversified and multi-directional, and allow different sound games on the Internet. At the same time, it is also possible to use foreign social media platforms to transmit and enhance information exchange with foreign public and communicate Chinese people's views on terrorism and counter-terrorism.

\subsection{Borrow External Forces and Increase Public Diplomacy}

The counter-terrorism strategic communications department of U.S. is set up under the Department of Public Diplomacy and Public Affairs under the State Council. It can be seen that they are more concerned with strategic communications from the perspective of public diplomacy. Although this model is designed according to the national conditions of the United States and its effectiveness remains to be seen, the importance we attach to public diplomacy deserves our reference.

In China's counter-terrorism strategic communications, we should give full play to the role of public diplomacy, make use of the platform of public diplomacy, strengthen exchanges and interaction with foreign public, and better communicate China's counter-terrorism ideas and policies, so as to enhance the knowledge and understanding of foreign public to the status quo of terrorism in China, China's counter-terrorist achievements and ideas.

\section{Conclusion}

When it comes to terrorism, it not only stresses the real influence terrorism has on the whole society, but the feature of communicating terrorist ideologies for political aims. Knowing about the long-term or mid-term objectives of terrorist groups, such as ISIS, Book Haram, Al-Qaeda and Haqqani network, it is clear that media has become a vital tool for terrorists to win in the battlefield of ideological war.

Many terrorists are turning to plural communication channels to low cost, be modernized and timely to construct their own system of terrorist discourse. The ultimate aim is to rejuvenate Islam. Therefore, communication should be put into a priority in counterterrorism fighting and deradicalization. Strategies of counterterrorism strategic communication should be made against terrorists" "terrorist strategic communication". Effective evaluation of terrorist activities must be done. Coordination of all the departments is indispensable in the process of making unanimous 
counterterrorism strategic communication strategies. On balance, soft and hard means need to be combined to combat terrorism.

\section{Acknowlegements}

This paper is sponsored by National Social Science Foundation of China (Grant No. 17CXW014) and Political and Legal Special Social Science Foundation of PPSUC (Grant No. 2018XKZTHY21).

\section{References}

[1]. Global Terrorism Index 2015. Institution for economics and peace.

[2]. http://economicsandpeace.org/wp-content/uploads/2015/11/Global-Terrorism-Index-2015.pdf.

[3]. Cottles S., Li Zhao Feng, Shi Lin: News, Public Relations and Power, Shanghai: The Press of Furan University, P89, 2007.

[4]. Gabriel Weismann. New Terrorism and New Media. Wilson Centre Research Series Vol2.https://www.wilsoncenter.org/sites/default/files/STIP_140501_new_terrorism_F.pdf.

[5]. Wang Yong: The Promotion of the strategic transformation of the International Counterterrorism Campaign, China Daily, March 3rd, 2016.

[6]. Baron, S.J. \& Davis, D.K... Mass communication theory: Foundations.

[7]. Ferment, and future. United States: Wadsworth.2010. 